\title{
CARDINAL KURT KOCH
}

The present volume highlights the vital topic of a Culture of CoExistence in Pluralistic Societies in the Middle East and in India. Dialogue between cultures and religions is the only way to peace and reconciliation. It helps us to rediscover the unity and harmony of the human family. Co-existence in a pluralistic society presupposes such dialogue, and entails reciprocal respect and mutual understanding.

Wherever there is a diversity of cultures, every person and therefore every Christian has the duty and right to participate fully in public life. In this respect, religious freedom is a sacred and inalienable right and finds its natural origin in the dignity of the person. Today we are called to share the daily sufferings of all those who are persecuted because of their religion, in the prayer that "from shared suffering can blossom forth forgiveness, reconciliation and peace, with God's help", as the Holy Father Pope Francis expressed it when he addressed His Holiness Coptic Pope Tawadros II during their meeting on 10 May 2013.

I wish to express my appreciation of the endeavours of eminent scholars who guide research in the field of promoting a culture of dialogue, religious harmony and, indeed, unity among Christians.

I especially thank the PRO ORIENTE Foundation for its steadfast and generous commitment to promoting Christian unity. Christians will speak more convincingly if they speak with one voice in addressing questions in contemporary pluralistic societies. United by one Baptism, we should walk together towards peace and harmony.

Kurt Cardinal Koch

President

Pontifical Council for Promoting Christian Unity, V atican 